\title{
MENAKAR HUBUNGAN ANTAR UMAT BERAGAMA DI KABUPATEN MAMUJU SULAWESI BARAT
}

\author{
Measuring The Relationship Among Inter-Religious People \\ In Mamuju Regency, West Sulawesi
}

\author{
Abd. Kadir $R$ \\ Balai Penelitian dan Pengembangan Agama Makassar \\ Jl. AP. Pettarani No.72 Makassar \\ Email: kadirrahman1957@gmail.com
}

Naskah diterima tanggal, 17 Februari 2015. Naskah direvisi tanggal, 10 Maret 2015. Naskah disetujui tanggal, 22 Mei 2015.

\begin{abstract}
Abstrak
Kerukunan antar umat beragama di Indonesia menjadi hal yang menarik untuk dikaji. Selama ini kondisi kerukunan beragama di Indonesia belum bisa dikatakan kondusif. Konflik antara umat beragama, konflik internal agama, kekerasan atas nama agama masih menjadi hal yang jamak kita saksikan. Di tengah itu masyarakat bangsa ini seperti kehilangan pegangan terhadap nilai-nilai luhur bangsa ini yang sangat menghargai perbedaan. Dalam konteks semacam itulah penelitian ini dilakukan. Penelitian tentang kerukunan umat beragama ini telah dilakukan secara berseri di kawasan Timur Indonesia. Salah satu daerah yang menjadi lokasi penelitian adalah Kabupaten Mamuju Sulawesi Barat, di mana penulis melakukan penelitian. Penelitian ini bertujuan untuk mengetahui sejauhmana indeks kerukunan umat beragama di Kabupaten Mamuju, dengan pendekatan penelitian kuantitatif. Penjaringan data dilakukan dengan penyebaran angket kepada responden sebanyak 360 orang yang menjadi sampel penelitian. Hasil penelitian menunjukkan bahwa dari empat variabel yang dipakai mengukur, hasil rata -rata indeks yang dicapai adalah 3,03 yang menujukkan kategori tinggi. Tingginya tingkat kerukunan ini ditunjang oleh kearifan lokal di daerah ini yang menjadi basis dalam mebangun kerukunan. Meski demikian, ada beberapa problem yang masih menjadi bantu sandungan dalam mengembangkan kerukunan yang lebih aktif. Yaitu belum adanya kesadaran pemeluk agama yang berbeda untuk hidup dan bekerja sama secara aktif.
\end{abstract}

Kata kunci: kerukunan, umat beragama, Kabupaten Mamuju.

\begin{abstract}
The harmony of inter-religious people in Indonesia is an interesting topic to study. During this state, the religious harmony in Indonesia cannot be claimed to be conducive. The conflicts among inter-religion, internal religion, violence in the name of religion still become the popular cases occurred. In addition, the people seem to lose the guidance toward the noble values of Indonesia which appreciate the differences. In this context, therefore, the research was conducted. The studies on the religious harmony have been carried out serially in eastern Indonesia. One of the areas as the research location was Mamuju, West Sulawesi. The research aims to identify to what extent the index of religious harmony in Mamuju. The research was quantitative method and collected data by distributing questionnaires to the respondents as many as 360 people as the selected samples. The results showed that through the four variables used to measure, the average index results achieved 3.03 which showed the high category. The high level of harmony was supported by local wisdom in this area that has become the basis in building harmony. However, there are some problems still becoming stumbling stone in developing harmony more actively; the lack of awareness of different religions to live and to cooperate actively.
\end{abstract}

Keywords: harmony, religious people, Mamuju. 


\section{PENDAHULUAN}

$\mathrm{K}$ erukunan beragama di Indonesia merupakan isu penting yang sudah sejak lama menjadi prioritas kebijakan pemerintah. Rencana undang-undang tentang kerukunan umat beragama ini masuk menjadi prioritas legislasi nasional. Selama ini yang menjadi rujukan mengenai kerukunan umat beragama biasanya adalah Peraturan Bersama Menteri (PBM) antara Menteri Dalam Negeri dan Menteri Agama No 9 dan No 8 tahun 2006. Hanya saja Peraturan Menteri dianggap tidak memadai dalam konteks pengelolaan kerukunan umat beragama saat ini.

Akhir-akhir ini persoalan kerukunan beragama menjadi masalah serius di Negara kita. Di tengah beragam agama dan beragam faham di internal masing-masing agama, kasus-kasus kekerasan atas nama agama kerap kali terjadi. Agama yang sejatinya adalah institusi yang mengembangkan kasih sayang, dalam realitasnya akhir-akhir ini menjadi landasan konflik di manamana.

Tidak hanya itu, jika merujuk ke beberapa laporan kebebasan beragama dan toleransi Setara Institut tercatat 367 tindakan pelanggaran kebebasan beragama/berkeyakinan dalam 265 peristiwa. Hal ini tentunya mencederai pula kerukunan beragama tersebut. Tiga provinsi menunjukkan angka pelanggaran yang sangat tinggi, yakni Jawa Barat (73 kasus), Sumatra Barat (56 kasus), dan Jakarta (45 kasus). Tiga provinsi ini memiliki tingkat toleransi yang rendah sekaligus menyimpan potensi konflik agama cukup tinggi. Laporan The Wahid Institute 2008 menunjukkan kecenderungan yang kurang lebih sama. Dalam laporan tahunan 2008 tentang pluralisme beragama/berkeyakinan tersebut, ada delapan kategori yang dicatat Wahid Institut selama tahun 2008, terdiri dari: 1) penyesatan terhadap kelompok/individu, baik yang dilakukan oleh masyarakat, Negara, maupun gabungan keduanya; 2) kekerasan berbasis agama; 3) regulasi bernuansa agama; 4) konflik tempat ibadah, seperti perusakan, problem perizinan, sengketa tanah dan hal-hal lain yang terkait; 5) kebebasan berfikir dan berekspresi; 6) hubungan antar umat beragama seperti isu penyebaran kebencian terhadap pemeluk agama lain; 7) fatwa-fatwa keagamaan dan; 8) moralitas dan pornografi yang meski tidak terkait langsung dengan agama, namun isu-isu moralitas dan pornografi tidak dapat dilepaskan dari pemahaman keagamaan. Dari 8 kategori itu ada lebih 200 kasus yang dianggap melanggar.

Penelitian tentang perspektif masyarakat tentang kerukunan umat beragama yang pernah dilakukan Litbang Agama Makassar pada tahun 2009 di Sulawesi Selatan, meski menunjukkan kecenderungan yang menggembirakan dengan indeks kerukunan yang baik, namun dalam beberapa variabel menunjukkan adanya problem. Misalnya, dalam soal penerimaan kelompok lain mendirikan rumah ibadah di lingkungannya, ratarata responden memilih tidak setuju. Pada tahun 2011, penelitian serupa dilaksanakan di Sulawesi Utara. Indeks kerukunan secara keseluruhan sangat baik, namun kesimpulan penelitian tersebut menunjukkan kerukunan terjadi hanya dipermukaan atau lazim disebut dengan toleransi pasif. Hal ini ditunjukkan dengan menurunnya tingkat persetujuan responden ketika terkait dengan persoalan pemberian bantuan terhadap rumah ibadah agama berbeda. Penelitian di Sulawesi Utara juga menunjukkan adanya kemungkinan terjadi konflik yang menjadikan agama sebagai basisnya bila tidak ada penanganan dengan baik. Penelitian ketiga tentang indeks kerukunan umat beragama, dilakukan Litbang Agama Makassar di Kalimantan Timur. Daerah ini pun menunjukkan indeks kerukunan beragama yang cukup menggembirakan berada pada level sangat baik. Namun, potensi yang bisa memecah belah kerukunan di daerah ini muncul dari persoalan etnisitas, seperti pertikaian etnis yang baru-baru ini terjadi di Kutai Barat. Hal ini bila tidak ditangani dengan baik akan berimbas pada kerukunan beragama masyarakat.

Dari ketiga penelitian tentang indeks kerukunan beragama yang telah dilakukan di tiga daerah tersebut, tampak kecenderungan bahwa dalam perspektif masyarakat, mereka rata-rata mendambakan atau mengidealkan kerukunan beragama tersebut. Namun, dalam tataran praktik ataupun hubungan sehari-hari nampak masih ada sekat-sekat, masih membangun tembok identitas primordialisme yang kokoh. Inilah yang perlu diretas dalam mengembangkan kerukunan beragama di beberapa daerah tersebut.

Pada sisi yang lain, hal ini menunjukkan bahwa kerukunan beragama yang selama ini dibangun, khususnya pada masa Orde Baru, sebenarnya lebih banyak terjadi di permukaan. Peraturan yang ada sebagimana yang telah disebutkan di atas, lebih banyak menjadi alat pemaksa dibanding sebagai sebuah regulasi yang berupaya untuk mengelola keragaman tersebut. 
Hal ini juga terkait dengan kebijakan secara umum dari pemerintah Orde Baru dalam mengelola keberagaman, termasuk keragaman agama. Meski bermunculan berbagai peraturan yang ditampilkan ke publik sebagai perekat dari keragaman tersebut, namun tujuan utamanya adalah penumbuhan identitas bangsa sebagai satu kesatuan nasional yang integratif. Dalam rangka ini, sentimen kebangsaan yang lebih sesuai untuk fungsi integratif itu adalah sebagaimana disinyalir oleh Ernest Gellner (2002), terkumpulnya manusia modular yang terintegrasi oleh kultur homogen. Gellner disini meyakini bahwa keragaman yang dirukunkan pada masa Orde Baru adalah mengintegrasikan semua perbedaan itu dalam satu kesatuan yang diawasi dengan diktum stabilitas.

Kerukunan yang dikurung oleh perspektif integrasionisme semacam ini biasanya memiliki kesuksesan terbatas, yakni sejauh kekuatan Negara masih memiliki legitimasi politik, yang mana seringkali legitimasi ini diperoleh melalui pemaksaan. Ini artinya bahwa, unsur-unsur penyatu dalam keragaman agama itu tidak lebih karena adanya ikatan politik yang disandarkan kepada wewenang Negara sebagai regulatornya. Begitu Negara mengalami kebangkrutan total, maka tidak ada lagi alasan untuk mengikatkan diri dalam tema kerukunan tersebut. Hal ini telah terbukti di Indonesia, begitu Orde Baru runtuh maka kerukunan itu mulai terkoyak-koyak .

Dengan demikian, kerukunan umat beragama saat ini perlu dilihat kembali dan ditelaah. Sejauh ini Kementerian Agama sendiri telah merumuskan kebijakan yang terkait dengan kerukunan beragama yang dijabarkan dalam Peraturan Menteri Agama RI tahun 2010 tentang Renstra Kementerian Agama 2010-2014. Ada lima hal pokok yang menjadi tanggung jawab Kementerian Agama dalam menyelenggarakan pembangunan bidang Agama, dua di antaranya adalah: 1) peningkatan kualitas kehidupan beragama; dan 2) peningkatan kerukuan umat beragama.

Mengingat pentingnya pemetaan kerukunan ini lebih komprehensif dan untuk menguji apakah kecenderungan di tiga daerah yang telah disebutkan di atas terjadi atau tidak di daerah lain, maka Litbang Agama Makassar kembali melakukan penelitian indeks kerukunan beragama di kawasan Timur Indonesia, salah satu di antaranya adalah Kabupaten Mamuju, provinsi Sulawesi Barat. Daerah ini sengaja dipilih karena melihat heterogenitas, bukan hanya dilihat sudut etnisitas, tapi juga heterogenitas dari segi penganut agama. Meskipun itu beberapa tahun yang lalu, ada dua kabupaten tetangganya yakni Kabupaten Mamasa dilanda konflik yang dikenal dengan konflik ATM. Dan di Kabupaten Poso Provinsi Sulawesi Tengah. Namun, konflik yang terjadi di dua daerah tersebut tidak berpengaruh di Kabupaten Mamuju.

Penelitian ini mengacu pada dua permasalahan, yakni: Bagaimana indeks kerukunan umat beragama di Kabupaten Mamuju; dan bagaimana potret kerukunan umat beragama di Kabupaten Mamuju.

Adapun tujuan penelitian ini adalah. Untuk mengetahui indeks kerukunan umat beragama di Kabupaten Mamuju, dan memetakan secara jelas potret kerukunan umat beragama di Kabupaten Mamuju.

\section{Tinjauan Pustaka \\ Kerukunan Beragama}

Istilah rukun pertama-tama merujuk pada state of well-being, sebuah kondisi keseimbangan sosial di mana semua pihak berada dalam keadaan damai satu sama lain, suka bekerja sama, saling menerima, dalam suasana tenang dan sepakat (Suseno,1993: 39). Kemudian Mulder (1978: 39) mendefinisikan "rukun" sebagai berada dalam keadaan selaras, tenang dan tenteram tanpa perselisihan dan pertentangan, bersatu dalam maksud untuk saling membantu. Menurut Hamdan, MM, kerukunan beragama berarti hubungan sesama umat beragama dilandasi toleransi, saling pengertian, saling menghormati, menghargai kesetaraan dalam pengamalan ajaran agamanya dan kerjasama dalam kehidupan bermasyarakat, berbangsa dan bernegara di dalam Negara Kesatuan Republik Indonesia berdasarkan Pancasila dan UUD RI tahun 1945.

Paradigma kerukunan ini ada beberapa, dalam tulisan Sabara mengutip Sukidi menyebutkan beberapa paradigma yang erat kaitannya dengan kerukunan beragama ini, di antaranya adalah inklusivisme, toleransi, dan pluralism. Inklusivisme sendiri adalah satu paham yang melihat bahwa kebenaran bukan hanya pada kelompoknya sendiri, karena itu mereka terbuka untuk berdialog dengan kelompok bahkan agama yang berbeda. Cak Nur memberikan satu penjelasan terhadap kerukunan beragama ini. Menurutnya, inklusivisme merupakan satu sikap yang bertujuan untuk menumbuhkan sikap kejiwaan yang melihat kemungkinan orang lain itu benar. Menurut Cak Nur hal ini didasarkan bahwa manusia dilahirkan semuanya dalam kondisi fitrah, maka pada dasarnya setiap orang benar dan 
suci. Tidak ada perubahan pada ciptaan manusia. Itulah agama yang lurus, tapi sebagian besar manusia tidak mengetahuinya” (Sabara, 2013).

Pandangan inklusivisme ini di samping muncul di kalangan Islam, namun bukan sematamata milik tradisi Islam. Dalam agama Kristen inklusivisme juga ada. Cerminannya dapat dilihat pada Konsili Vatikan II. Dalam dokumen konsili Vatikan II disebutkan bahwa ada keselamatan di luar gereja pada tahun 1965, konsili Vatikan II mengeluarkan satu keputusan penting. Pertama orang yang tidak dibaptis, tanpa kesalahan, tidak percaya pada Allah tapi berjalan sesuai dengan hati nuraninya dapat diselamatkan. Kedua, setiap orang berhak mengikuti agama yang diyakininya. Ketiga, umat Katholik dianjurkan menghormati apa yang baik dalam agama-agama lain (Franz Magnis, 2005).

Selain inklusivisme, paradigma lain yang dianggap terkait dengan kerukunan umat beragama adalah toleransi. Toleransi berasal dari bahasa Latin, yakni tolerantia yang berarti kelonggaran, kelembutan hati, keringanan dan kesabaran. Michael walzer menyebutkan setidaknya lima substansi toleransi yaitu: 1) menerima perbedaan untuk hidup damai; 2) menjadikan keseragaman menjadi perbedaan; 3) menerima bahwa orang lain memiliki hak; 4) mengekspresikan keterbukaan terhadap orang lain, ingin tahu, menghargai, ingin mendengarkan dan belajar dari yang lain; dan 5) dukungan yang penuh terhadap perbedaan dan menekankan aspek otonomi (Walzer, 1997).

Toleransi sendiri terdiri dari dua paradigma yaitu toleransi aktif dan pasif. Toleransi aktif ini adalah toleransi yang tidak sekedar menerima perbedaan sebagai hukum alam, tapi juga aktif dalam mengelola perbedaan itu dan ada keinginan untuk bekerja sama. Sementara yang pasif hanya melihat perbedaan sebagai satu kenyataan yang harus diterima.

Paradigma lain adalah pluralisme. Pluralisme ini semacam perkembangan dari inklusivisme. Inklusivisme menunjukkan persamaan pada sisi substansial pada yang lain, sedang pluralisme meyakini adanya perbedaan-perbedaan. Pluralisme juga memungkinkan kerja sama dalam konteks perbedaan dengan memulainya pada proses dialog.

Jika kita melihat pendapat Diana L Eck, dia menekankan pluralism pada tiga hal: Pertama, pluralisme adalah aktif berpartisipasi dalam keragaman. Kedua, memahami yang berbeda dengan pemahaman yang benar. Ketiga, pluralisme adalah upaya menemukan komitmen bersama di tengah perbedaan.
Selain ketiga hal tersebut, masih ada satu paham baru yang terkait dengan persoalan keragaman yaitu multikulturalisme. Namun, yang terakhir ini tidak semata-mata terkait dengan keragaman agama. Multikulturalisme juga punya perhatian besar terhadap isu-isu minoritas. Istilah ini tidak persis sama dengan paham keragaman budaya karena penekanannya di sini pada pengakuan terhadap hak minoritas (Abu Hamid, 2004:1).

Konsep kerukuan umat beragama dalam konteks penelitian ini dimaksudkan sebagai hubungan antar umat beragama yang dilandasi saling penghargaan dan keinginan untuk bekerjasama dengan penganut agama yang berbeda. Dalam penelitian kerukunan umat beragama yang digunakan adalah toleransi dalam konsep Walzer yaitu: 1) menerima perbedaan untuk hidup damai; 2)menjadikan keseragaman menjadi perbedaan; 3) menerima bahwa orang lain memiliki hak; 4) mengekspresikan keterbukaan terhadap orang lain, ingin tahu, menghargai, ingin mendengarkan dan belajar dari yang lain; dan 5) dukungan yang penuh terhadap perbedaan dan menekankan aspek otonomi.

\section{Variabel dan Indikator Penelitian}

Adapun variabel penelitian sebagai berikut:

1. Hubungan sosial (menerima perbedaan untuk damai dan mengubah keseragaman menjadi perbedaan, ingin tahu, menghargai dan belajar dari orang yang berbeda);

2. Menerima bahwa yang lain memiliki hak dukungan penuh terhadap perbedaan melalui kebijakan pemerintah, dengan sembilan indikator;

3. Dukungan penuh terhadap perbedaan (peran organisasi masyarakat dan lingkungan dalam mendukung toleransi dan perbedaan);

4. Kearifan lokal dan peran ormas

\section{METODE PENELITIAN}

Penelitian ini menggunakan metode penelitian kuantitatif. Dengan tehnik penentuan sampel, pengumpulan dan analisis data sebagai berikut:

\section{Populasi dan sampel}

Dalam penelitian ini, yang dimaksudkan dengan populasi adalah masyarakat (seluruh penganut agama) di Kabupaten Mamuju. Adapun jumlah sampel ditentukan dengan menggunakan rumus Slovin, dimana $n=N / 1+N . d^{2}$ 
$\mathrm{n}=$ Besaran sampel

$\mathrm{N}=$ Jumlah Populasi

$\mathrm{d}=$ Galat Pendugaan (Dugaan tingkat Kesalahan, untuk penelitian ini yang digunakan adalah 0,03).

Kemudian penentuan dilakukan secara proforsional berdasarkan persentasi penganut agama dari seluruh penduduk. Penentuan sampel ini dilakukan secara Stratified Random Sampling (Bambang dan Lina, 2005).

\section{Pengumpulan dan Analisa Data}

Pengumpulan data dilakukan dengan membagikan angket kepada responden. Selain membagikan angket, juga dilakukan wawancara secara terstruktur maupun tidak terstruktur kepada beberapa informan.

Analisa data yang digunakan adalah analisis statistik dengan melihat indeks kerukunan beragama. Rumus yang digunakan adalah:

IKUB = Jumlah total nilai jawaban

Nilai terbaik (Jumlah pertanyaan(...)xjumlah Responden x4

Selanjutnya IKUB ini akan dilihat berada pada criteria mana. Adapun kriterianya adalah sebagai berikut.

$1-1.9=$ Sangat rendah

$2-2.5=$ Rendah

$2.6-3.5=$ Tinggi

$3.6-4=$ Sangat Tinggi

\section{PEMBAHASAN}

\section{Identifikasi Lokasi Penelitian}

Kabupaten Mamuju yang dikenal dengan sebutan Bumi Manakarra yang berarti pusaka petunjuk mulia, merupakan salah satu diantara lima kabupaten yang ada di Provinsi Sulawesi Sulawesi Barat, dan sekaligus menjadi ibukota provinsi. Luas wilayahnya sebanyak $7.942,76 \mathrm{Km}^{2}$, yang terbagi atas enam belas kecamatan, terdiri atas 155 desa, 10 kelurahan, serta 2 Unit Pemukiman Transmigrasi (UPT).Enam belas kecamatan tersebut mempunyai luas wilayah yang bervariasi.

Menurut data sensus penduduk tahun 2011, penduduk yang mendiami Kabupaten Mamuju sebanyak 349.571 jiwa, terdiri atas laki-laki sebanyak 179.896 jiwa, dan perempuan sebanyak 169.675 jiwa. Jumlah penduduk tersebut tersebar pada 16 kecamatan yang ada dalam wilayah Kabupaten Mamuju, dengan jumlah yang bervariasi pada setiap kecamatan. Kecamatan yang paling banyak penduduknya adalah Kecamatan Mamuju, yang berjumlah 57.165 jiwa (16,35\%).Kecamatan Mamuju merupakan ibukota kabupaten. Sedangkan kecamatan paling sedikit jumlah penduduknya adalah Kecamatan Balabalakang, sebanyak 2.435 jiwa(0,69\%). Kecamatan Balabalakang merupakan kecamatan pemekaran dari Kecamatan Simboro.

Penduduk Kabupaten Mamuju mengalami pertumbuhan yang cukup signifikan yakni rata-rata $3,5 \%$ pertahun. Sebagai gambaran jumlah penduduk pada tahun 2007 sebanyak 296.828 jiwa, kemudian pada tahun 2008 jumlah penduduk bertambah menjadi 305.473 jiwa, dan pada tahun 2009 menjadi 315.053 jiwa, 2010336973 , pada tahun 2011, jumlah penduduk mencapai 349.571 jiwa.

Apalagi setelah provinsi Sulawesi Barat resmi terbentuk 22 September 2014 berdasarkan UndangUndang No 26 yang ditetapkan tanggal 5 Oktober 2004 (Idham dan Safrillah, 2010:182) dan kabupaten Mamuju ditetapkan sebagai ibu kota provinsi, maka Kabupaten Mamuju sudah mulai dilirik dan didatangi orang dari daerah lainnya, untuk mengadu nasib. Ada beberapa faktor yang menarik orang lain mendatangi Kabupaten Mamuju, di antaranya kekayaan sumber daya alamnya yang cukup potensial untuk menjadi lahan ekonomi. Misalnya dari hasil perkebunan yang menghasilkan coklat dan kelapa sawit. Kemudian dari segi pertambangan, menurut hasil survey bahwa Kabupaten Mamuju mengandung potensi alam yang cukup menjanjikan seperti, emas, batu bara, marmer dan minyak . Faktor lainnya adalah sebagai provinsi yang baru terbentuk dan menjadikan Kabupaten Mamuju sebagai ibukota Provinsi, dengan sendirinya membutuhkan banyak tenaga kerja untuk diangkat menjadi pegawai negeri. Sehingga Kabupaten Mamuju dihuni oleh penduduk yang hetrogen dari suku bangsa. Selain etnis Mandar yang merupakan penduduk asli, juga dihuni oleh etnis pendatang, seperti Bugis, Makassar, Jawa, Toraja dan lain-lain.

Selain itu budaya orang Mamuju sangat terbuka terhadap orang pendatang. Masyarakat yang terbuka itu tetap saja memegang teguh adat yang kemudian menjadi perekat dari heterogenitas yang ada. Hal ini berdasarkan pada falsafah persaudaraan yang dimiliki oleh mereka yang berbunyi: ampunna ni inung do uwai marandanna to mamunyu, to mamunyu mo ittu tau. Artinya kalau sudah meminum air jernihnya orang Mamuju, maka telah menjadi orang Mamuju (Muis, 2004).

Di Kabupaten Mamuju terdapat lima agama yang berkembang, yakni Agama Islam, 
Kristen, Katolik, Hindu, dan Buddha. Dari kelima agama tersebut, agama Islam yang paling banyak penganutnya, yakni sebanyak 279.652 orang $(80 \%)$ dari seluruh penganut agama di Kabupaten Mamuju. Agama lainnya yang paling banyak penganutnya adalah agama Kristen, dengan jumlah penganut sebanyak 39.256 orang(11,22\%). Kemudian yang ketiga yang banyak penganutnya adalah agama hindu, dengan jumlah penganut sebanyak 6.263 orang $(1,78 \%)$ disusul kemudian agama Katolik, dengan jumlah penganut sebanyak 3.700 orang $(1,05$ $\%)$. Dan yang paling sedikit jumlah penganutnya adalah agama Buddha dengan jumlah penganut 1.149 orang $(0,32 \%)$ dari jumlah penganut agama di Kabupaten Mamuju. Dari lima agama tersebut di atas, hanya penganut agama Islam yang tersebar secara merata di lima belas kecamatan yang ada dalam wilayah Kabupaten Mamuju, sedangkan empat agama lainnya, penganutnya tidak tersebar secara merata pada semua kecamatan yang ada.

Penganut setiap agama tersebut dapat melaksanakan kegiatan ibadahnya karena ditunjang oleh sarana yang cukup tersedia. Bagi penganut agama Islam sarana ibadah tersedia sebanyak 803 buah, dengan rincian 604 buah berupa mesjid, dan 197 buah berupa mushallah. Kemudian untuk penganut agama Kristen sebanyak 258 buah, dan Katolik tersedia sarana ibadah berupa gereja sebanyak 35 buah. Sedangkan bagi penganut agama Hindu dan Buddha sarana ibadahnya tersedia 31 pura bagi penganut agama Hindu, dan 18 buah bagi penganut agama Buddha.

\section{Identitas Responden}

Penelitian tentang kerukunan umat beragama yang mengambil lokasi Kabupaten Mamuju dengan pendekatan kuantitatif. Responden yang menjadi sampel penelitian ini sebanyak tiga ratus orang. Untuk mengetahui latar belakang responden tersebut, maka berikut ini akan diuraikan identitasnya sebagai berikut.

Responden yang menjadi sampel penelitian terdiri atas laki-laki sebanyak 160 orang (53,3\%), dan perempuan sebanyak 140 orang $(46,7 \%)$ yang berasal dari latar belakang agama yang berbedabeda. Dari tiga ratus orang yang menjadi sampel penelitian, sebahagian besar di antaranya, yakni sebanyak 231 orang (77\%) yang beragama Islam. Responden terbanyak kedua adalah beragama Kristen, yakni sebanyak 53 orang, disusul yang beragama Hindu sebanyak 10 orang (3,3\%). Dan responden yang paling sedikit adalah yang beragama Katholik sebayak 6 orang (2\%). Untuk jelasnya dapat dilihat pada grafik berikut.

Grafik 1. Jumlah Responden Menurut Latar Belakang agama

\section{a islam $\square$ kristen $\square$ hindu $\square$ katolik}

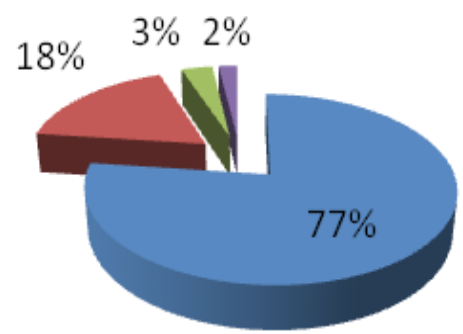

Sumber: data kuesioner yang diolah

Selain berasal dari latar belakang agama yang bervariasi, juga berasal dari latar belakang pendidikan yang berbeda pula, dengan latar belakang tingkat pendidikan SMA keatas yang memiliki porsi terbesar, yakni sebanyak 283 orang (93, 7\%), sedangkan responden yang berpendidikan tingkat SMP ke bawah hanya 17 orang $(6,3 \%)$. Adapun responden yang memiliki tingkat pendidikan SMA keatas, dapat diuraikan sebagai berikut. Responden yang memiliki tingkat pendidikan SMA sebanyak 111 orang (37\%); diploma sebanyak 47 orang (15, 7\%); dan responden yang memiliki tingkat pendidikan sarjana S2, S2, dan S3 sebanyak 125 (41 \%). Selain itu sebanyak 17 orang responden yang memiliki tingkat pendidikan rendah, dengan uraian sebagai berikut. SMP sebanyak 13 orang $(4,3 \%)$ dan SD sebanyak 4 orang $(1,3 \%)$.

Selain itu bidang pekerjaan yang digeluti oleh responden, juga nampak bervariasi. Pekerjaan yang paling banyak digeluti oleh responden adalah Pegawai Negri Sipil (PNS) yakni sebanyak 133 orang $(44,3 \%)$ dari 300 orang responden yang menjadi sampel penelitian. Pekerjaan terbanyak kedua yang digeluti oleh responden adalah menjadi karyawan / swasta yakni sebanyak 86 orang (28, $7 \%)$. Kemudian disusul bidang pekerjaan yang bervariasi( lainnya) sebanyak 42 orang (14\%), berstatus pelajar/ mahasiswa sebanyak 23 orang $(7,7 \%)$; pedagang sebanyak 13 orang $(4,3 \%)$. Untuk jelasnya dapat dilihat pada grafik berikut: 
Grafik 2. Jumlah Responden Menurut Pekerjaan

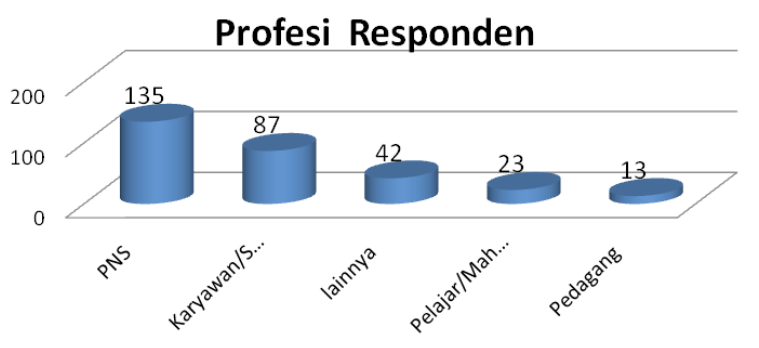

Sumber: Data kuesioner yang diolah.

\section{Indeks Kerukunan Berdasarkan Variabel}

Analisis tentang indeks kerukunan umat beragama di Kabupaten Mamuju diperoleh hasil rata-rata 3,03 (kategori tinggi). Nilai indeks tersebut diperoleh dari empat variabel yang dipakai mengukur indeks kerukunan umat Beragama di Kabupaten Mamuju. Keempat variabel tersebut adalah, hubungan sosial (menerima perbedaan untuk hidup damai dan mengubah keseragaman menjadi perbedaan, ingin tahu, menghargai dan belajar dari orang yang berbeda); menerima bahwa yang lain memiliki hak; dukungan penuh terhadap perbedaan melalui kebijakan pemerintah; dan kearifan lokal dan peran organisasi masyarakat. Dari empat variabel tersebut kearifan lokal dan peran organisasi masyarakat memiliki nilai indeks paling tinggi yakni 3,13, dan variabel yang memiliki nilai indeks paling rendah adalah hubungan sosial yakni 2,9. Untuk jelasnya dapat dilihat pada tabel berikut:

Tabel 1. Indeks Kerukunan Umat Beragama

\begin{tabular}{clcc}
\hline No & \multicolumn{1}{c}{ Variabel } & Indeks & kategori \\
\hline 01 & Hubungan Sosial(Menerima Perbedaan untuk hidup damai dan mengubah & 2,9 & Tinggi \\
& $\begin{array}{l}\text { keseragaman menjadi perbedaan, ingin tahu, menghargai dan belajar dari orang yang } \\
\text { berbeda }\end{array}$ & & \\
02 & Menerima bahwa yang lain memiliki Hak & 3,09 & Tinggi \\
03 & Dukungan Penuh Terhadap Perbedaan Melalui Kebijakan Pemerintah & 3,01 & Tinggi \\
04 & Kearifan Lokal dan Peran Organisasi Masyarakat & 3,14 & Tinggi \\
& & 3,03 & Tinggi \\
\hline Sumber: data kuesioner yang diolah & &
\end{tabular}

Data dalam tabel di atas menunjukkan bahwa variabel yang berkaitan hubungan sosial memiliki indeks paling rendah dibanding nilai indeks tiga variabel lainnya. Dari data tersebut mengindikasikan bahwa hubungan sosial antar penganut agama di Kabupaten Mamuju masih ada gejala kurang harmonis, meskipun selama ini tidak pernah terjadi konflik. Selain itu variabel tentang kearifan lokal dan peran organisasi masyarakat memiliki nilai indeks paling tinggi yakni 3,13 (kategori tinggi). Hal ini mengindikasikan bahwa kearifan lokal dan organisasi sosial masih fungsional dalam merawat kerukunan umat beragama di Kabupaten Mamuju. Selanjutnya akan diuraikan tentang analisis indeks kerukunan antar umat beragama berdasarkan variabel.

\section{Hubungan Sosial}

Kerukunan antar umat beragama yang berkaitan dengan hubungan sosial. Variabel ini diukur melalui 9 indikator atau sub variabel. Dari Sembilan indikator atau sub variabel yang dipakai mengukur indek variabel tersebut, ada tiga sub variabel yang memiliki indeks paling tinggi,namun disisi lain terdapat pula tiga sub variabel yang memiliki indeks yang rendah dengan nilai indeks di bawah tiga. Untuk jelasnya dapat dilihat pada tabel berikut.

Tabel 2. Indeks Hubungan Sosial

\begin{tabular}{clcc}
\hline No & \multicolumn{1}{c}{ Indikator Variabel } & Indeks & kategori \\
\hline 01 & Bergaul akrab dengan orang berbeda agama & 3,14 & Tinggi \\
02 & Mengundang orang beda agama di rumah/acara & 3,07 & Tinggi \\
03 & Menghadiri acara orang beda agama & 2,99 & Tinggi \\
04 & Melakukan transaksi jual beli dengan orang beda agama & 3,05 & Tinggi \\
05 & Memberi bantuan dana orang beda agama & 2,81 & Tinggi \\
06 & Membantu pembangunan rumah ibadah agama lain & 2,43 & Tinggi \\
07 & Berkunjung pada tetangga beda agama & 3,04 & Tinggi \\
08 & Tidak keberatan jika ada aliran agama tertentu melakukan kegiatan keagamaan disekitar & 2,71 & Tinggi \\
& tempat tinggal & & Tinggi \\
\hline & Mendengar saran dan pendapat tokoh agama lain & Nilai indeks rata-rata & 2,88 \\
\hline
\end{tabular}


Data pada tabel di atas menggambarkan bahwa ada tiga sub variabel yang berkaitan dengan hubungan sosial yang memiliki nilai indeks tinggi dengan nilai di atas 3 . Tiga sub variabel dimaksud adalah bergaul dengan orang beda agama dengan nilai 3,14 (kategori Tinggi). Hal ini sesuai dengan pernyataan responden yang sebahagian besar, yakni sebanyak 210 orang responden(70\%) dari 300 orang responden yang dijadikan sampel penelitian menyatakan menyatakan setuju, bahkan sebanyak 69 orang (23\%) menyatakan sangat setuju. Kemudian responden yang menyatakan kurang setuju sebanyak 17 orang (5,7\%). Sedangkan responden yang menyatakan tidak setuju, hanya 4 orang $(1,3 \%)$.

Di samping itu ada satu sub variabel yang memiliki indeks yang masuk kategori rendah. Sub variabel tersebut adalah membantu pembangunan rumah ibadah agama lain. Sub variabel ini memiliki nilai indeks 2,43 (kategori rendah). Nilai ini berdasarkan pernyataan responden yang lebih separuh memberikan apresiasi negatif. Dari 300 orang yang dijadikan sampel penelitian, sebanyak 100 orang $(33,3 \%)$ menyatakan kurang setuju. Dan bahkan sebanyak 52 orang (17,3\%) menyatakan tidak setuju. Di sisi lain sebanyak 114 orang (38\%) menyatakan setuju. Kemudian responden yang menyatakan sangat setuju sebanyak 34 orang (11,3\%).

Apabila variabel hubungan sosial dikaitkan dengan agama yang dianut responden, maka gambarannya seperti pada tabel berikut.

Table 3. Hubungan Sosial dikaitkan dengan agama Responden

\begin{tabular}{cccccc}
\hline \multirow{2}{*}{ Agama } & \multicolumn{4}{c}{ Hubungan Sosial } & Total \\
\cline { 2 - 5 } & $\begin{array}{c}\text { Sangat } \\
\text { Buruk }\end{array}$ & Buruk & Baik & $\begin{array}{c}\text { Sangat } \\
\text { baik }\end{array}$ & \\
\hline Islam & 1 & 35 & 188 & 8 & 232 \\
Kristen & 0 & 2 & 43 & 8 & 53 \\
Katolik & 0 & 0 & 3 & 2 & 5 \\
Hindu & 0 & 0 & 7 & 3 & 10 \\
Total & 1 & 37 & 241 & 21 & 300 \\
\hline Sumber: data Kuesioner Yang diolah
\end{tabular}

Data pada tabel di atas menunjukkan bahwa sebanyak 241 orang responden (80,33\%) memiliki indeks kategori tinggi, yang berasal dari responden yang beragama islam sebanyak 188 orang. Kemudian responden yang beragama Kristen sebanyak 43 orang; beragama Hindu sebanyak 7 orang. Dan responden beragama Katholik sebanyak 3 orang.
Kemudian responden yang memiliki nilai indeks kategori sangat tinggi sebanyak 21 orang (7\%) yang berasal dari responden yang menganut agama Islam sebanyak 8 orang. Dan responden yang menganut agama Hindu dan Katholik, masingmasing 3 orang dan 2 orang.

Disisi lain sebanyak 37 orang (12,33\%) responden yang memiliki nilai indeks rendah, yang berasal dari responden yang menganut agama islam sebanyak 35 orang, penganut agama Kristen sebanyak 2 orang. Bahkan terdapat satu orang yang memiliki nilai indeks sangat rendah, yang berasal dari penganut agama islam.

Kemudian variabel hubungan sosial dikaitkan dengan tingkat pendidikan responden, maka gambarannya seperti pada tabel berikut.

Tabel 4. Variabel Hubungan Sosial dikaitkan dengan tingkat pendidikan Responden

\begin{tabular}{cccccc}
\hline \multirow{2}{*}{ Pendidikan } & \multicolumn{4}{c}{ Hubungan Sosial } & Total \\
\cline { 2 - 5 } & $\begin{array}{c}\text { Sangat } \\
\text { Buruk }\end{array}$ & Buruk & Baik & $\begin{array}{c}\text { Sangat } \\
\text { baik }\end{array}$ & \\
\hline Tamat SD & 0 & 1 & 3 & 0 & 4 \\
Tamat SMP & 0 & 3 & 10 & 0 & 13 \\
Tamat SMA & 1 & 16 & 84 & 10 & 111 \\
Diploma & 0 & 4 & 39 & 4 & 47 \\
S!/S2/S3 & 0 & 13 & 105 & 7 & 125 \\
Total & 1 & 37 & 241 & 21 & 300 \\
\hline Sumber: Data kuesioner Yang diolah & & &
\end{tabular}

Data pada tabel di atas menggambarkan bahwa sebahagian besar responden, yakni sebanyak 241 orang dari 300 orang yang menjadi sampel penelitian memiliki indeks kategori tinggi. Responden yang memiliki indeks tinggi tersebut berasal dari responden yang memiliki tingkat pendidikan S1 keatas, dan inilah yang paling banyak dibanding responden lainnya yakni sebanyak 105 orang. Kemudian responden yang berpendidikan SMA sebanyak 84 orang; responden yang berpendidikan Diploma sebanyak 39 orang; responden tamat SMP 10 orang. Sedangkan responden berpendidikan SD sebanyak 3 orang. Bahkan sebanyak 21 orang responden yang memiliki indeks sangat tinggi, yang berasal dari responden yang memiliki tingkat pendidikan sebanyak 10 orang; responden yang memiliki tingkat pendidikan S1 keatas sebanyak 7 orang, dan berpendidikan Diploma sebanyak 4 orang.

Disisi lain sebanyak 37 orang memiliki indeks kategori rendah, dan satu orang meiliki indeks 
sangat rendah. Responden yang memiliki indeks kategori rendah tersebut berasal dari responden yang memiliki tingkat pendidikan SMA sebanyak 16 orang; S1 keatas sebanyak 13 orang; Diploma sebanyak 4 orang. Sedangkan responden yang berpendidikan SMP dan SD masing-masing 3 orang dan 1 orang. Kemudian responden yang memiliki indeks kategori sangat rendah hanya satu orang yang berasal dari responden yang memiliki tingkat pendidikan SD.

Demikian pula, jika variabel hubungan sosial dikaitkan dengan pekerjaan responden. Hal ini dapat diuraikan sebagai berikut. Dari empat kategori nilai indeks yang ada, maka sebahagian besar responden yang memiliki indeks kategori tinggi, yakni sebanyak 241 orang dari 300 orang yang dijadikan sampel penelitian. Responden yang memiliki nilai indeks kategori tinggi, terdiri atas, PNS sebanyak 114 orang; karyawan/swasta sebanyak 68 orang; lainnya( ibu rumah tangga, penjual jasa) sebanyak 19 orang; pelajar/mahasiswa sebanyak 19 orang; dan pedagang sebanyak 11 orang.

Selain memiliki indeks kategori tinggi, bahkan sebanyak 21 orang yang memiliki indeks kategori sangat tinggi, yang terdiri atas, karyawan/ swasta sebanyak 11 orang; PNS sebanyak 7 orang. Kemudian responden yang menggeluti tiga macam pekerjaan yakni pelajar, pedagang, dan lainnya masing-masing satu orang.

Di sisi lain sebanyak 37 orang responden yang memiliki kategori rendah, dan ada satu orang yang memiliki indeks kategori sangat rendah. Responden yang memilki indeks kategori rendah berasal dari responden yang bekerja sebagai Pegawai Negri Sipil (PNS) sebanyak 14 orang; lainnya 11 orang; karyawan 8 orang; pelajar 3 orang; dan pedagang 1 orang.

\section{Menerima Bahwa Yang Lain Memiliki Hak.}

Variabel yang berkaitan dengan penerimaan responden bahwa yang lain memiliki hak, diukur melalui 9 indikator atau sub variabel. Variabel ini memiliki nilai indeks rata-rata 3,09 (kategori tinggi), dengan nilai indeks per sub variabel tidak merata. Untuk jelasnya dapat dilihat pada tabel berikut.
Tabel 5. Indeks Variabel Menerima Bahwa yang Lain Memiliki hak

\begin{tabular}{|c|c|c|c|}
\hline No & Indikator Variabel & Indeks & Kategori \\
\hline 1 & $\begin{array}{l}\text { Melakukan tindak } \\
\text { kekerasan terhadap } \\
\text { agama lain,dilarang } \\
\text { semua agama }\end{array}$ & 3,41 & tinggi \\
\hline 2 & $\begin{array}{l}\text { Menganggap pendapat } \\
\text { sendiri paling benar } \\
\text { dan tidak menghargai } \\
\text { pendapat orang } \\
\text { lain dapat merusak } \\
\text { hubungan antara agama }\end{array}$ & 2,95 & tinggi \\
\hline 3 & $\begin{array}{l}\text { Pemerintah wajib } \\
\text { memberikan pelayanan } \\
\text { keagamaan, menfasilitasi } \\
\text { dan membantu semua } \\
\text { agama }\end{array}$ & 3,33 & tinggi \\
\hline 4 & $\begin{array}{l}\text { Saya tidak } \\
\text { mempersoalkan jika } \\
\text { ada agama melakukan } \\
\text { perayaan keagamaan di } \\
\text { lingkungan saya }\end{array}$ & 3,05 & tinggi \\
\hline 5 & $\begin{array}{l}\text { Saya bersedia berdamai } \\
\text { dengan orang yang } \\
\text { pernah berkonflik } \\
\text { dengan, seagama } \\
\text { maupun beda agama }\end{array}$ & 3,26 & tinggi \\
\hline 6 & $\begin{array}{l}\text { Tokoh agama yang } \\
\text { menyudutkan agama } \\
\text { lain bisa memicu konflik }\end{array}$ & 3,11 & tinggi \\
\hline 7 & $\begin{array}{l}\text { Saya tidak keberatan jika } \\
\text { ada penganut agama lain } \\
\text { ingin mendirikan rumah } \\
\text { ibadah di lingkungan } \\
\text { saya }\end{array}$ & 2,74 & tinggi \\
\hline 8 & $\begin{array}{l}\text { Pembangunan } \\
\text { rumah ibadah harus } \\
\text { dilakukan dengan jalan } \\
\text { musyawarah dengan } \\
\text { penganut agama lain } \\
\text { yang ada disekitar }\end{array}$ & 3,22 & tinggi \\
\hline 9 & $\begin{array}{l}\text { Penyebaran agama tidak } \\
\text { boleh dilakukan pada } \\
\text { penganut agama lain }\end{array}$ & 2,77 & tinggi \\
\hline & Nilai indeks rata-rata & 3,09 & tinggi \\
\hline
\end{tabular}

Data pada tabel 5 di atas menunjukkan bahwa dari sembilan indikator variabel yang dipakai mengukur indeks, ada dua indikator variabel memiliki nilai indeks paling tinggi. Namun disisi lain juga terdapat dua indikator variabel yang memiliki nilai indeks yang paling rendah.

Kedua sub indikator yang memiliki nilai indeks yang tinggi adalah sub variabel 3, dengan nilai indeks 3,33 (kategori tinggi). Nilai indeks ini sejalan dengan pernyataan responden yang sebahagian besar yakni sebanyak 185 orang $(61,7 \%)$ yang menyatakan setuju, dan bahkan sebanyak 109 
orang ( $36,3 \%)$ menyatakan sangat setuju. Kemudian disisi lain ada 6 orang responden yang memberikan apresiasi negatif, dengan kategori kurang setuju sebanyak 3 orang( $1 \%)$ dan tidak setuju hanya satu orang (1\%).

Indikator variabel lainnya yang memiliki nilai indeks yang tinggi adalah sub variablel 5 , dengan nilai indeks 3,26 (kategori tinggi). Hal ini sejalan dengan pernyataan responden yang sebahagian besar responden, yakni sebanyak 204 orang (68\%) dari 300 orang responden yang dijadikan sampel menyatakan setuju. Dan bahkan sebanyak 88 orang $(29,3 \%)$ menyatakan sangat setuju. Selain itu, sebanyak 7 orang responden yang menyatakan kurang setuju, dan tidak setuju, masing-masing 4 orang dan 3 orang.

Kemudian sub variabel atau indikator yang memiliki nilai indeks yang paling rendah adalah sub variabel 7 . Sub variabel tersebut memiliki nilai indeks 2,74 (kategori tinggi). Meskipun masih dalam kategori tinggi, namun sudah mendekati kategori buruk. Nilai indeks tersebut berdasarkan pernyataan responden yang menyatakan setuju sebanyak 190 orang $(63,3 \%)$ dari 300 orang responden yang dijadikan sampel penelitian. Dan 28 orang $(9,3 \%)$ menyatakan sangat setuju.

Di samping itu sebanyak 60 orang responden (20\%) yang menyatakan kurang setuju. Bahkan sebanyak 22 orang responden $(7,3 \%)$ yang menyatakan tidak setuju.

Apabila variabel tersebut (menerima bahwa yang lain memiliki hak) dikaitkan dengan agama yang dianut responden, maka gambarannya seperti pada tabel berikut:

Tabel 6 . Kaitan agama responden dengan variabel menerima bahwa yang lain memiliki hak

\begin{tabular}{rccccc}
\hline \multirow{2}{*}{ Agama Responden } & \multicolumn{2}{c}{ Menerima bahwa yang lain memiliki hak } & \multirow{2}{*}{ Total } \\
\cline { 3 - 5 } & & 2.(buruk) & 3(baik) & 4(sangat Baik) & \\
\hline \multirow{2}{*}{ AGAMA } & Islam & 19 & 201 & 12 & 232 \\
& Kristen & 1 & 41 & 11 & 53 \\
Katolik & 0 & 3 & 2 & 5 \\
\multicolumn{2}{r}{ Hindu } & 0 & 7 & 3 & 10 \\
\multicolumn{2}{c}{ Total } & 20 & 252 & 28 & 300 \\
\hline \multicolumn{2}{l}{ Sumber: data kuesioner yang diolah }
\end{tabular}

Data pada tabel di atas menunjukkan bahwa dari 300 orang responden yang dijadikan sampel penelitian, sebahagian besar yakni sebanyak 252 orang $(84 \%)$ yang memiliki nilai indeks 3 (kategori tinggi). Responden yang memilki kategori baik tersebut berasal dari responden yang beragama Islam sebanyak 201 orang. Kemudian responden yang beragama Kristen sebanyak 41 orang; Hindu sebanyak 7 orang; dan Katolik sebanyak 3 orang. bahkan sebanyak 28 orang responden $(9,33 \%)$ yang memiliki nilai indeks 4 (kategori sangat tinggi), yang berasal dari responden yang beragama Islam sebanyak 12 orang; beragama Kristen sebanyak 11 orang, Hindu dan katolik, masing-masing 3 orang dan 2 orang. Namun, disisi lain sebanyak 20 orang yang memilki nilai indeks 2 (kategori rendah). Responden tersebut berasal dari responden beragama Islam sebanyak 19 orang, Kristen satu orang.

Dari data di atas pula dapat dibaca bahwa responden dari empat penganut agama yang menjadi sampel penelitian sebahagian besar memiliki nilai indeks 3 (tinggi) dan indeks 4 (sangat tinggi). Untuk jelasnya dapat diuraikan sebagai berikut. Penganut agama Islam dari 232 orang yang menjadi sampel penelitian sebanyak 201 orang $(86,64 \%)$ memiliki nilai indeks 3 (baik), dan 12 orang (5,17\%) memiliki nilai indeks 4 (sangat tinggi). Dan hanya 19 orang $(8,18 \%)$ memiliki nilai indeks 2 (rendah).

Kemudian responden beragama Kristen, dari 53 orang yang menjadi sampel penelitian, sebanyak 4lorang $(77,35 \%)$ yang memiliki nilai indeks 3 (tinggi), bahkan 11 orang $(20,75 \%)$ yang memiliki nilai indeks 4 (sangat tinggi). Sedangkan responden yang memiliki nilai indeks 2 (rendah) hanya satu orang $(1,88 \%)$.

Penganut agama katolik 3 orang (60\%) dari 5 orang yang menjadi sampel penelitian memiliki nilai indeks 3 (tinggi), bahkan 2 orang (40\%) yang memiliki nilai indeks 4 (sangat tinggi). Dan tidak ada satu orang pun yang memiliki nilai indeks 2 (rendah).

Demikian pula halnya penganut agama hindu, sebanyak 7 orang (70\%) dari 10 orang yang dijadikan sampel memiliki nilai indeks 3 (tinggi), bahkan 3 orang (30\%) diantaranya memiliki nilai indeks 4 (sangat tinggi). 


\section{Dukungan Penuh Terhadap Perbedaan Melalui Kebijakan Pemerintah}

Variable ini mencoba menyorot kebijakan pemerintah dalam mendukung kerukunan umat beragama di Kabupaten Mamuju. Ada 8 sub variabel atau indikator yang dipakai mengukur indeks kerukunan melalui kebijakan pemerintah. Setelah dianalisis maka nilai indeks rata-rata dari 8 sub variabel atau indikator adalah 3,01. Dari 8 sub variabel atau indikator 4 di antaranya memiliki nilai indeks di atas 3 dan 4 lainnya memiliki nilai indeks di bawah 3. Lihat pada tabel berikut:

Tabel. 7 Indeks Variabel Dukungan Penuh Terhadap Perbedaan Melalui Kebijakan Pemerintah

\begin{tabular}{|c|c|c|c|}
\hline No & Sub Variabel/indikator & indeks & kategori \\
\hline 1 & Pembangunan rumah ibadah semua agama telah mendapat jaminan dari pemerintah & 3,07 & Tinggi \\
\hline 2 & Keterlibatan Pemerintah dapat mempercepat proses penyelesaian konflik & 3,25 & Tinggi \\
\hline 3 & $\begin{array}{l}\text { Pemerintah selama ini telah melindungi kelompok yang mendapatkan tindakan } \\
\text { kekerasan dari kelompok/aliran lain }\end{array}$ & 2,82 & Tinggi \\
\hline 4 & $\begin{array}{l}\text { Pemerintah selama ini telah menindak tegas organisasi keagamaan yang selalu } \\
\text { melakukan tindakan kekerasan }\end{array}$ & 2,96 & Tinggi \\
\hline 5 & $\begin{array}{l}\text { Pemerintah selama ini telah memfasilitasi dialog antara kelompok agama yang berbeda } \\
\text { pandangan }\end{array}$ & 2,95 & Tinggi \\
\hline 6 & Pemerintah tidak boleh mencampuri praktik-praktik ibadah agama tertentu & 2,62 & Tinggi \\
\hline 7 & $\begin{array}{l}\text { Pemerintah selama ini telah bekerja sama dengan tokoh agama untuk meningkatkan } \\
\text { kerukunan umat beragama }\end{array}$ & 3,26 & Tinggi \\
\hline 8 & $\begin{array}{l}\text { Pemerintah sebaiknya memprogramkan kurikulum kerukunan beragama dalam muatan } \\
\text { kurikulum local }\end{array}$ & 3,12 & Tinggi \\
\hline & Nilai Indeks Rata-rata & 3,01 & Tinggi \\
\hline
\end{tabular}

Sumber data kuesioner yang diolah.

Data pada tabel menunjukkan bahwa subvariabel atau indikator variabel yang berkaitan dengan kerja sama pemerintah dengan tokoh agama dalam meningkatkan kerukunan umat beragama memiliki nilai indeks tertinggi dari delapan sub variabel atau indikator variabel yang dipakai mengukur indeks variabel dukungan penuh terhadap perbedaan melalui kebijakan pemerintah. Sub variabel tersebut memiliki nilai indeks 3,26 (kategori tinggi). Nilai indeks tersebut berdasarkan pernyataan responden yang sebahagian besar yakni sebanyak 184 orang responden $(61,3 \%)$ dari 300 orang responden yang menjadi sampel penelitian menyatakan setuju. Dan bahkan sebanyak 99 orang responden $(33,9 \%)$ menyatakan sangat setuju. Namun, di sisi lain sebanyak 15 orang responden (5\%) menyatakan kurang setuju, dan hanya 2 orang responden $(0,7 \%)$ menyatakan tidak setuju.

Sub variabel lainnya yang memiliki nilai indeks tertinggi adalah keterlibatan pemerintah dapat mempercepat proses penyelesaian konflik, dengan nilai indeks 3, 25 (kategori baik). Hal ini berdasarkan sebahagian besar responden, yakni sebanyak 194 orang responden (64,7\%) menyatakan setuju. Bahkan sebanyak 93 orang responden (31\%) menyatakan sangat setuju. Selain itu sebanyak 5 orang responden $(2,7 \%)$ menyatakan kurang setuju.
Kemudian yang menyatakan tidak setuju, hanya 5 orang responden $(1,7 \%)$ dari 300 orang yang menjadi sampel penelitian.

Sedangkan sub variabel atau indikator variabel yang memiliki nilai indeks paling rendah adalah, pemerintah tidak boleh mencampuri praktik-praktik ibadah agama tertentu. Sub variabel tersebut memiliki nilai indeks 2,62 (kategori tinggi). Meskipun nilai indeks sub variabel tersebut masih dalam kategori tinggi, namun sudah mendekati kategori rendah.

Data grafik di atas menunjukkan bahwa sub variabel yang berkaitan dengan campur tangan pemerintah dalam praktik-praktik ibadah agama tertentu mendapat apresiasi negatif yang cukup banyak dari responden, yakni sebanyak 82 orang responden $(27,3 \%)$ dari 300 yang menjadi sampel penelitian menyatakan kurang setuju. Dan bahkan 37 orang responden $(12,3 \%)$ menyatakan tidak setuju. Menurut responden yang kurang setuju dan tidak setuju menyatakan bahwa masalah ajaran agama dan praktik ibadah merupakan urusan penganut agama yang bersangkutan yang tidak perlu dicampuri oleh pemerintah.

Kemudian jika dikaitkan dengan asal agama responden maka gambarannya dapat dilihat pada tabel berikut: 
Tabel. 8 Variabel Dukungan terhadap Perbedaan Melalui Kebijakan Pemerintah dikaitkan Agama Responden

\begin{tabular}{ccccc}
\hline \multirow{2}{*}{ Agama } & \multicolumn{4}{c}{ Hubungan Sosial } \\
& Rendah & Tinggi & Sangat Tinggi & Total \\
\hline Islam & 65 & 166 & 1 & 232 \\
Kristen & 13 & 39 & 1 & 53 \\
Katolik & 2 & 3 & 0 & 5 \\
Hindu & 1 & 8 & 1 & 10 \\
\hline Total & 81 & 216 & 3 & 300 \\
\hline Sumber: data kuesioner yang diolah
\end{tabular}

Table di atas menggambarkan bahwa sebahagian besar responden yakni sebanyak 216 orang responden (72\%) yang memiliki indeks kategori baik, yang berasal dari responden beragama islam sebanyak 166 orang; responden beragama Kristen sebanyak 39 orang; responden beragama hindu sebanyak 8 orang; responden beragama katolik sebanyak 3 orang. Kemudian responden yang memiliki nilai indeks kategori sangat baik, hanya 3 orang, yang berasal dari responden beragama islam,Kristen, dan hindu masing-masing satu orang.

Disisi lain sebanyak 81 orang responden (28\%) yang memiliki nilai indeks kategori buruk. Responden yang memiliki nilai indeks kategori buruk tersebut berasal dari responden beragama islam sebanyak 65 orang, responden beragama, Kristen sebanyak 13 orang, responden beragama katolik sebanyak 2 orang. Sedangkan responden yang beragama hindu hanya satu orang.

Data pada tabel di atas menggambarkan pula bahwa masing- masing penganut agama yang dijadikan sampel penelitian sebahagian besar memiliki nilai indeks kategori baik. Hal ini dapat diuraikan sebagai berikut. Responden yang beragama Islam, dari 232 orang yang menjadi sampel penelitian, sebanyak 166 orang yang memiliki nilai indeks kategori baik. Dan satu orang memiliki nilai indeks kategori sangat baik.

Kemudian responden yang beragama Kristen, 39 orang dari 53 orang yang menjadi sampel penelitian meiliki nilai indeks kategori baik, dan satu orang kategori sangat baik. Demikian pula responden yang beragama hindu, yang memiliki nilai indeks kategori baik sebanyak 8 orang, dari 10 orang yang menjadi sampel penelitian. Sedangkan responden yang beragama katolik, 3 orang diantaranya memilki nilai indeks kategori baik, dari 5 orang yang menjadi sampel penelitian.
Pada sisi lain sebanyak 65 orang yang beragama islam memiliki nilai indeks kategori buruk, responden beragama Kristen sebanyak 13 orang, 2 orang beragam katolik, dan hanya satu orang yang beragama Hindu.

Kemudian jika variabel tersebut dikaitkan dengan tingkat pendidikan responden, maka gambarannya seperti pada tabel berikut:

Tabel. 9 Hubungan Tingkat Pendidikan Responden dengan Variabel Dukungan Penuh terhadap Perbedaan Melalui Kebijakan Pemerintah

\begin{tabular}{ccccc}
\hline $\begin{array}{c}\text { Pendidikan } \\
\text { Responden }\end{array}$ & Rendah & Tinggi & $\begin{array}{c}\text { Tategori Indeks } \\
\text { Tinggi }\end{array}$ & \\
\hline Tamat SD & 0 & 4 & 0 & 4 \\
Tamat SMP & 6 & 7 & 0 & 13 \\
Tamat SMA & 30 & 80 & 1 & 111 \\
Diploma & 8 & 39 & 0 & 47 \\
S!/S2/S3 & 37 & 86 & 2 & 125 \\
\hline Total & 81 & 216 & 3 & 300 \\
\hline
\end{tabular}

Sumber: data kuesioner yang diolah

Responden yang memiliki kategori baik mendominasi indeks kerukunan jika dilihat kaitan veriabel dukungan penuh terhadap perbedaan melalui kebijakan pemerintah dalam kaitannya dengan tingkat pendidikan responden. Hal ini berasal dari responden yang memilki tingkat pendidikan S1 ke atas sebanyak 86 orang; tingkat SMA sebanyak 80 orang; Diploma sebanyak 39 orang; SMP sebanyak SMP sebanyak 7 orang; SD sebanyak 4 orang.

\section{Kearifan Lokal dan Peran Organisasi Masyarakat.}

Indeks variabel tersebut diukur melalui tujuh sub variabel atau indikator variabel. Secara umum nilai indeks rata-rata variabel tersebut adalah 3,14 (kategori baik). Dari tujuh indikator variabel, nilai indeks tertinggi adalah 3,25 yang diperoleh indikator variabel organisasi keagamaan sebaiknya terlibat aktif dalam meningkatkan kerukunan umat beragama. Sedangkan nilai indeks terendah adalah indikator variabel organisasi keagamaan sebaiknya memberikan dukungan perayaan hari besar agama, terhadap agama yang berbeda. Untuk jelasnya dapat dilihat pada tabel berikut: 
Tabel 10. Indeks Variabel Kearifan Lokal dan Peran Ormas

\begin{tabular}{|c|c|c|c|}
\hline No & Indikator Variabel & Indeks & kategori \\
\hline 1 & $\begin{array}{l}\text { Organisasi keagamaan } \\
\text { sebaiknya terlibat dalam } \\
\text { meningkatkan kerukunan } \\
\text { umat beragama }\end{array}$ & 3,25 & Tinggi \\
\hline 2 & $\begin{array}{l}\text { Nilai local soal keragaman } \\
\text { dapat meningkatkan } \\
\text { kerukunan umat beragama }\end{array}$ & 3,13 & Tinggi \\
\hline 3 & $\begin{array}{l}\text { Tokoh adat dan tokoh } \\
\text { masyarakat selama ini } \\
\text { telah dilibatkan dalam } \\
\text { meningkatkan kerukunan } \\
\text { umat beragama }\end{array}$ & 3,03 & Tinggi \\
\hline 4 & $\begin{array}{l}\text { Peran tokoh adat sangat } \\
\text { penting dalam menciptakan } \\
\text { keharmonisan dalam } \\
\text { kehidupan masyarakat }\end{array}$ & 3,22 & Tinggi \\
\hline 5 & $\begin{array}{l}\text { Tokoh adat dan tokoh agama } \\
\text { harus mendorong masyarakat } \\
\text { di lingkungannya menerima } \\
\text { dan mau bekerjasama dengan } \\
\text { orang yang berbeda agama }\end{array}$ & 3,22 & Tinggi \\
\hline 6 & $\begin{array}{l}\text { Nilai local yang bisa } \\
\text { mendorong kerukunan umat } \\
\text { beragama, sebaiknya menjadi } \\
\text { muatan kurikulum }\end{array}$ & 3,08 & Tinggi \\
\hline 7 & $\begin{array}{l}\text { Organisasi keagamaan } \\
\text { sebaiknya memberikan } \\
\text { dukungan perayaan hari besar } \\
\text { agama, terhadap agama yang } \\
\text { berbeda. }\end{array}$ & 3,02 & baik \\
\hline & Nilai Indeks Rata-rata & 3,14 & Tinggi \\
\hline
\end{tabular}

Sumber: data kuesioner yang diolah

Tabel di atas menunjukkan bahwa semua indikator variabel yang yang dipakai mengukur berkaitan dengan kearifan lokal dan peran organisasi masyarakat memiliki nilai indeks di atas 3 , tertinggi dibandingkan dengan tiga variabel yang lain

\section{Membaca Indeks 3,03}

Seperti telah dikemukakan pada pembahasan terdahulu bahwa indeks kerukunan umat beragama di Kabuapten Mamuju mencapai nilai 3,03 (kategori Tinggi). Capaian indeks diperoleh dari empat variabel yang dipakai mengukur indeks kerukunan umat beragama di Kabupaten Mamuju, yakni: 1) hubungan sosial, menerima perbedaan untuk hidup damai dan mengubah keseragaman menjadi perbedaan, ingin tahu, menghargai dan belajar dari orang yang berbeda; 2) menerima bahwa yang lain memiliki hak; 3) dukungan penuh terhadap perbedaan melalui kebijakan pemerintah; dan 4) kearifan lokal dan peran organisasi masyarakat.

Dari empat variabel yang dipakai mengukur indeks kerukunan umat beragama di Kabupaten Mamuju, variabel kearifan lokal dan peran organisasi masyarakat memiliki nilai indeks tertinggi dibanding variabel lainnya, yakni 3,13 (kategori
Tinggi). Hal ini dapat difahami bahwa kearifan lokal dan peran organisasi masyarakat masih sangat fungsional dalam mendukung terciptanya kerukunan umat beragama di Kabupaten Mamuju.

Menurut salah seorang informan bahwa meskipun penduduk Kabupaten Mamuju sangat heterogen, baik suku bangsa, maupun agama, namun selama ini tidak pernah terjadi konflik yang bernuansa Sara, maupun bernuansa agama, sebagaimana pernyataan Al Malik Pababari sebagai berikut, konflik memang tak pernah terdengar di Mamuju. Heterogenitas tak dijadikan alasan pembenaran untuk anarkis. Kami saling menjaga dan menghormati sesama warga walau berbeda agama dan suku. Justru keragaman itu menjadi kekuatan kami dalam membangun Mamuju (dalam Muis, 2004: 50).

Seirama dengan pernyataan Pababari tersebut, salah seorang pendeta gereja Toraja Mamasa mengatakan sebagai berikut: memang kita harus mengakui perbedaan, dan memang kita harus berbeda. Dalam kalangan agama Kristen saja terjadi perbedaan, tapi jangan perbedaan tersebut yang dibesar-besarkan, justru kita harus meminimalisir perbedaan, dan mencari titik persamaannya. (wawancara Pendeta di Mamuju, 20/9/2013 di Mamuju).

Masyarakat Kabupaten Mamuju sangat terbuka terhadap penduduk pendatang, sebagaimana falsafah hidup yang dipegang oleh masyarakat sebagai berikut: ampunna ni inung do uwai marandanna to mamunyu, to mamunyu mo ittu tau. Artinya kalau sudah meminum air jernihnya orang Mamuju, maka telah menjadi orang Mamuju (Muis, 2004: 154).

Falsafah hidup lainnya yang diperpegangi oleh masyarakat Kabupaten Mamuju dalam menunjang kerukunan umat beragama adalah .." massetto ada' tau' massetto nyama, manjulu sara manjulu rio, massetto pattaro di lante samballa, setto kalingulu nisolai. Arti bebasnya sebagai berikut: Bersatu menjunjung adat, bersatu pada hati, duka sama rasa, riang sama terasa, bersatu tekad di sehelai tikar, satu bantal dua kepala.

Faktor lainnya yang mendukung terpeliharanya kerukunan umat beragama adalah peran organisasi masyarakat, pemerintah, dan tokoh adat. Di Kabupaten Mamuju terbentuk Forum Komunikasi umat beragama (FKUB), yang dipimpin oleh Mahyuddin, S.Ag. Peran yang dilakukan oleh FKUB dalam menciptakan kerukunan melakukan kegiatan bekerjasama dengan kementerian agama, mengadakan pertemuan dengan tokoh-tokoh 
agama. Kegiatan ini dilaksanakan satu kali dalam tiga bulan, dan pada akhir tahun dilakukan refleksi akhir tahun dengan melibatkan tokoh agama, tokoh masyarakat dan tokoh adat (wawancara di Mamuju, 25/9/2013).

\section{PENUTUP}

Penduduk Kabupaten Mamuju merupakan masyarakat heterogen, baik dilihat suku bangsa, maupun dari segi pemeluk agama. Meskipun heterogen, namun kerukunan umat beragama tetap terjaga. Hal ini dapat dilihat dengan capaian nilai indeks yakni rata-rata 3,03 (kategori tinggi). Dari empat variabel yang dipakai mengukur indeks kerukunan umat beragama di Kabupaten Mamuju, tiga variabel di antaranya memiliki nilai indeks 3 bahkan lebih, dan variabel kearifan lokal dan organisasi masyarakat memiliki indeks paling tinggi, dengan nilai indeks 3,14 (kategori tinggi). Hal ini menunjukkan bahwa kearifan lokal dan tokoh masyarakat yang tergabung dalam organisasi masyarakat, masih fungsional dalam memelihara kerukunan umat beragama di Kabupaten Mamuju.

Disisi lain variabel hubungan sosial memiliki nilai indeks yang paling rendah dengan nilai indeks 2,9. Hal ini dapat dibaca bahwa hubungan antar umat beragama masih terjadi jarak, meskipun selama ini tidak terjadi konflik. Ada beberapa sub variabel yang berkaitan dengan variabel hubungan sosial yang memiliki nilai indeks rendah diantaranya, variabel membantu pembangunan rumah ibadah agama lain, dengan nilai indeks 2,43 (kategori buruk). Sub variabel tidak keberatan jika ada aliran agama tertentu melakukan kegiatan keagamaan di sekitar tempat tinggalnya, dengan nilai indeks 2,71. Sub variabel lainnya adalah memberi bantuan dana kepada orang berbeda agama, dengan nilai indeks 2,81(kategori baik).

\section{UCAPAN TERIMA KASIH}

Penelitian ini dapat terlaksana dengan melalui beberapa tahap, mulai dari pengumpulan data sampai pada penulisan laporan dan penulisan makalah. Namun demikian, penelitian ini tidak berhasil tanpa bantuan beberapa pihak. Oleh karena itu peneliti mengucapkan terima kasih kepada Kepala Balai Litbang Agama Makassar yang telah memberi kesempatan untuk melakukan penelitian, informan lapangan yang memberikan informasi, dan redaksi Al Qalam yang bersedia memuat tulisan ini untuk dipublikasikan.

\section{DAFTAR PUSTAKA}

Abu Hamid, 2004. Kesadaran Multikulturalisme Dalam Kehidupan Berbangsa dan Bernegara (makalah) disampaikan dalam seminar "Dialog Budaya Sulawesi Selatan tanggal 16 Juni 2004 di PKP Universitas Hasanuddin.

BPS. 2012. Kabupaten Mamuju Dalam Angka tahun 2012.

Bungin, Burhan. 2006. Metode penelitian Kuantitatif. Jakarta: Kencana Media Group.

Hamdan. 2008. Kerukunan Umat Beragama, http:// www, win2pdf. com

Litbang Agama Makassar. 2008. Jarak Sosial Umat Beragama di Kawasan Indonesia Timur. .2009. Potret Kerukunan Umat beragama di Sulawesi Selatan. 2012. Potret Kerukunan Umat Beragama di Kalimantan Timur. . 2011. Potret Kerukunan Umat Beragama di Sulawesi Utara.

Misrawi, Zuhairi. 2007. Al Quran Kitab Toleransi. Jakarta: Fitrah Publishing.

Mulder, Niels. 1978. Mysticism and Everyday Life in Contemporary Java: Cultural Persistence and Change. Singapore: University Press.

Parekh, Bikhu. 2000. Rethinking Multikulturalism: Cultur Diversity and Political Theory. London: Mc Milan.

Prasetyo, Bambang dan Linah Miftahul Jannah. 2005. Metode Penelitian Kuantitatif Metode dan Aplikasi. Jakarta: Raja Grafindo Persada.

Sabara, 2013. "Potret Kerukunan Beragama pada Masyarakat Multikultural". Jurnal Al-Fiqr. Vol.17. No. 3

Sukidi, 2001. "Teologi Inklusif Cak Nur", Kompas, Jakarta.

Suseno, Frans Magnis. 2005. Pluralisme Dalam Sengketa. Makalah di sampaikan dalam seminar Tafsir Aktual atas Pluralisme 12 Oktober 2005.

1993. Etika Jawa: Sebuah Analisa falsafi Tentang Kebijaksanaan Hidup Jawa. Jakarta: Gramedia

Walzer, Michael. 1997. On Toleration. New Haven and London: Yale University Press.

Idham dan Saprillah. 2010. Sejarah Perjuangan Pembentukan Provinsi Sulawesi Barat. Solo: Zada Haniva Publishing.

Muis, Asdar RMS. 2004. Almalik Pababari Merajut Masa Depan Mamuju. Makassar: Intermedia Publishing. 